\title{
Partial maternal separation and adult emotionality in BALB/c mice
}

RICIIARD C: LaBARBA, ROBERT LLTZ. and JERRY WIITL. University of Somah Fitrida, Tampa, Florida

Twenty-foul h after birth, BALB/c mice were separated from their mothers every o $h$, around the clock, for ls consecutive days. When tested for emotionality at 50 days of age, the experimental group was significantly less active than the control group in an open field. Two other dependent measures, quadrants traversed and defecation, did not yield significant differences between the experimental and control groups. The results are interpreted as failing to confirm the hypothesis of increased emotionality as a function of maternal separation. The problem of emotionality measures in mice is discussed.

The literature dealing with early experiential effects on adult behavior suggests that most forms of extra stimulation of organisms during early infancy result in decreased emotionality. Denenberg (1964) has hypothesized that the reduction in emotionality is a function of the amount of stimulation during infancy, and that this relationship assumes the form of an inverted $\mathrm{U}$ function. Several studies point to the significance of mother-infant relations with regard to ontogenetic factors contributing to emotionality in the adult organism (Barnett \& Burn, 1967; Denenberg, Hudgens, \& Zarrow, 1966; Denenberg, Ottinger, \& Stephens, 1962; LaBarba, 1967; Newton \& Levine, 1968; Reading, 1966; Young, 1965). In addition, Ressler (1962) has reported findings which strongly indicate that the quantitative and qualitative characteristics of mother-infant relations between two strains of mice differ significantly, and that these differences in maternal behavior cannot be attributed to genetic factors. According to Denenberg, we would expect to find differences in adult emotionality as a function of the general stimulation input of the infants resulting from differences in maternal behavior patterns. Organisms deprived of maternal stimulation, either fully or partially, would therefore suffer from a reduction in their general stimulus input level, and subsequently evidence developmental impairment in the behavioral form of increased emotionality.

Several studies show the detrimental effects of maternal separation in organisms ranging from the cat to Rhesus monkeys (Newton \& Levine, 1968). Newell (1967), in a study concerning the effect of maternal deprivation in two strains of mice, did not obtain the results predicted by Denenberg's hypothesis, insofar as he failed to find any consistent treatment effects on emotional reactivity. In the present study, it was hypothesized that the concomitant reduction in stimulation which occurs as a function of maternal separation would result in an increase in emotionality. The procedures used in this study differ in several important aspects from those of Newell.

Twenty BALB/c strain of mice were used, obtained from six litters from nulliparous females. The litters used in the study all contained five or less animals in order to control for any effects due to litter size. Three litters totalling 10 infants were assigned to the treatment group. From a large number of litters bred for controls, three litters were assigned as a control group, matched for litter size and sex. All animals were raised in standard polyethylene cages in our laboratory. The cages contained wood shavings for nesting material. The animals in the treatment group were separated from the mother by removing the mother for $6 \mathrm{~h}$, and then returning her to the infants for a 1-h period to nurse them. At the end of the $1-h$ feeding period, the mother was again removed for 6 consecutive $h$. This procedure was followed around the clock for 18 days, beginning $24 \mathrm{~h}$ after parturition until 19 days of age. The infant mice were never handled during this period. and were not disturbed in any way during the first 50 days of life. The control group was raised under the same laboratory conditions, and was not disturbed during the first 50 days of life.
The mothers in this group were removed trom the home cage and placed in the same kind of plastic cage as the experimental group mothers, but for a period of only 2 min. This was done to control for any effects due to handling mothers. The infants in the treatment group thus were exposed to their mothers for a period of only $3 \mathrm{~h}$ out of every $24 \mathrm{~h}$. a sharp reduction in stimulus input. All animals were weancel at 20 days of age, remaining in their original cages until the study was completed. Emotionality was measured over a 3-min period over three days, from 50 days of age to 52 days. The apparatus was a Lehigh Valley automated quadrant activity cage, a circular cage measuring 18 in. in diameter and 15 in. in height. Equipped with photoelectric cells and a tilt floor connected to a bank of counters and a four pen event marker, this apparatus automatically records activity and quadrants traversed. In addition to these two measures, defecation was collected as dropped through the grid floor. The floor of the cage was washed with vinegar after each animal was given its daily 3-min trial in order to remove odors. A mixed design analysis of variance was computed for each dependent measure over the three-day testing period.

The analysis of variance for the dependent measures of quadrants traversed and defecation did not yield any significant $F$ ratios. There were no significant main effects or interactions between the experimental and control groups. The analysis on the measure of activity level, however, did yield a significant $F$ ratio between treatment groups. The experimental group was significantly more "emotional" than the control group as measured by the dependent variable of activity level $(F=4.56$, $\mathrm{d} f=1 / 16, p<.05)$. No other significant effects were found on the activity measure.

It can be seen that the mean score for the experimental group (197.43) is considerably lower than that for the control group (254.33). Activity is typically interpreted to be an index of emotionality, with some exceptions (Hayes, 1960; Welker, 1959).

The failure of the other two dependent measures to converge with the measure of activity level weakens the claim for increased emotionality as a function of maternal deprivation in this study, and the data is considered to be generally inconsistent with the results predicted by Denenberg's hypothesis of infantile stimulation and emotionality. To venture beyond the statement that maternally deprived $\mathrm{BALB} / \mathrm{c}$ mice show less motor activity than controls would be contentious. Some further considerations of emotionality measures in mice, at this point, are warranted. In several unpublished studies dealing with emotionality in mice, the writer has never obtained unequivocal evidence that defecation in mice is as reliable an index of emotionality as it is in rats. The correlation of this measure with other measures of emotionality has usually been found to be inconsistent and variable. At this point, the writer is not convinced that defecation in mice has any real meaning as an index of emotionality. In another study (LaBarba, unpublished manuscript), defecation in unhandled mice was found to increase significantly as a function of days tested in the open field. These findings are substantiated by Collins (1966) who obtained the same results in four strains of mice. Collins suggests that defecation in mice may not be solely an index of emotionality. Similarly, Bruell (1963) argues that defecation in

Table 1

Mean Activity Level Scores

\begin{tabular}{|c|c|c|c|c|c|c|c|}
\hline \multirow[b]{2}{*}{ Days } & \multicolumn{3}{|c|}{ Experimental } & \multicolumn{3}{|c|}{ Control } & \multirow[t]{2}{*}{$\mathrm{X}$} \\
\hline & 1 & 2 & 3 & 1 & 2 & 3 & \\
\hline Males & 158 & 209.5 & 204.7 & 279.2 & 274.2 & 241.5 & 227.04 \\
\hline Females & 180 & 234.8 & 190.8 & 303.1 & 219. & 221.3 & 224.86 \\
\hline$\overline{\mathrm{x}}$ & & 197.43 & & & 254.33 & & \\
\hline
\end{tabular}


mice is a territorial response and not an emotional one. With regard to activity measures, Welker (1959) views increased activity as attempts to escape from the situation, and that the active rat is fearful.

It is clear, then, that there are some serious challenges to the interpretation of the dependent variables which have been used to measure emotionality in rodents. It is felt that these arguments are particularly cogent with regard to mice in view of the above mentioned findings, and the growing feeling that the species differences in terms of emotional behavior may be much greater than previously assumed. It seems that it is now necessary to reconsider the behavioral measures typically used to assess emotionality in rodents and to exercise much more caution in the indiscriminate application of "emotionality" criteria not only across species but also across strains of animals.

\section{REFERENCES}

BARNETT, S. A., \& BURN, J. Early stimulation and maternal behavior. Nature, 1967, 213, 150-151.

BRUELL, J. H. Emotional defecation in mice: A territory marking response? Paper presented at the annual meeting of the American Psychological Association, 1963, New York.

COLLINS, R. L. What else does the defecation score measure? Paper presented at the annual meeting of the American Psychological Association, 1966, New York.
DENENBERG, V. H. Critical periods, stimulus input, and emotional reactivity: A theory of infantile stimulation. Psychological Review, 1964, $71,335-351$.

DENENBERG, V. H., HUDGENS, G. A., \& ZARROW, M. X. Mice reared with rats: Effects of mother on adult behavior patterns. Psychological Reports, 1966, 18, 451-456.

DENENBERG, V. H., OTTINGER, D. R., \& STEPHENS, M. W. Effects of maternal factors upon growth and behavior of the rat. Child Development, 1962, 33, 65-71.

LaBARBA, R. C. Emotionality in two strains of mice as a function of maternal handling. Psychonomic Science, 1967, 9, 121-122.

NEWELL, T. G. Effects of maternal deprivation on later behavior in two inbred strains of mice. Psychonomic Science, 1967, 9, 119-120.

NEWTON, G., \& LEVINE, S. (Eds.), Early experience and behavior. Springfield: Thomas, 1968.

READING, A. J. Effects of maternal environment on the behavior of inbred mice. Joumal of Comparative \& Physiological Psychology, 1966, 62, 437.440.

RESSLER, R. H. Parental handling in two strains of mice reared by foster parents. Science, 1962, 137, 129-1 30.

WELKER, W. I. Escape, exploratory, and food-seeking responses of rats in a novel situation. Journal of Comparative \& Physiological Psychology, 1959, $52,106-111$.

YOUNG, R. Influence of neonatal treatment on maternal behavior: A confounding variable. Psychonomic Science, 1965, 3, 295-296. 